\title{
Will Durant and the Rich Argosy of Literary Legacy
}

\author{
Prof.V.V.Hanumantha Rao \\ Head, Department of English, Sri Vasavi Engineering College, \\ Pedatadepalli, Tadepalligudem, Andhra Pradesh, India \\ vvhrao@yahoo.com
}

\begin{abstract}
Literature is the tip of an iceberg. Many a time it does not throw even a hint of what caused its manifestation and, its impulses and motifs are mostly submerged in the abysmal waters of history. An understanding of history makes our knowledge of literature more profound and meaningful. Will Durant stands towering over the rest in providing the readers of world literature with this mystic wisdom of times and climes. Durant gave the quintessence of his 11 volume magnum opus, 'The Story of Civilization', which traverses 110 centuries of human civilization and which he composed in an unbelievable peregrination of more than five decades, in his prodigious work 'Heroes of History' which could be described as an introduction to the catena of his books. Durant's unique standpoints and unforeseen observations bestow appropriate criteria for a perspicacious understanding and synthesis of the world literature. This paper attempts to bring to light a few insights and critical analyses of Durant regarding the recurring themes in literature as well as certain less known facets and impulses which characterize the personalities and works of the two glorious figures of renaissance, viz., William Shakespeare and Francis Bacon.
\end{abstract}

Keywords: History, Literature, Leit Motif, Renaissance, Civilization.

\section{INTRODUCTION}

Who else would readily tell us that the apocalyptic expression 'Armageddon' came from the bloodsoaked battle city 'Megiddo' where the Egyptian army defeated the Jews in 609 B.C.? Who else than Will Durant could enlighten us, by quoting from Diogenes Laertius, that it was Pythagoras who first named the universe 'Kosmos' (cosmos) meaning 'Order'.

With an uncanny blend of history, culture, politics, art, poetry and biography, Will Durant, the celebrated author of 'The Story of Civilization', the 11 volume magnum opus which traverses 110 centuries of human civilization and which he composed in an unbelievable peregrination of more than five decades, has left for the literati a lasting treasure, a study of which bestows appropriate criteria for a perspicacious understanding and synthesis of the world literature. To cut the labors of his readers short, Durant has given the quintessence of his prodigious work in what could be described as an introduction to the catena, viz., 'Heroes of History'.

\section{Leit Motifs: The Mystic RecurRences of Theme}

Will Durant, who is basically held in deference as a historian and social philosopher, has given extremely rare insights into literature which serve as leading lighthouses in a journey through the vast sea of literature. He has pointed out striking parallels in literature, the leit motifs - the mystic reoccurrences of theme, style and message - cutting across millennia, nations and languages.

Every student of literature knows the unputdownable vigor of Shelly's 'Prometheus Unbound', but only a handful would know about the leit motif that links it with the ancient 'Prometheus Bound' of Aeschylus, one of the 'Trio of Greek Tragedy'. Durant brings to light, not mere history but the 'theme', the enigmatic will of time, thus:

"He told the story of a man who had challenged the gods by teaching men the arts of fire and civilization, and was punished, at Zeus' command, by being chained to a rock in the caucusus and having his heart eaten out by a vulture and respectfully restored and eaten again. In the lost conclusion of a trilogy, Aeschylus showed Prometheus making his peace with Zeus, but the theme of man's revolt against a cruel deity survived through twenty-two centuries to find wild utterance in Shelly's Prometheus Unbound." (Will Durant 2001, p.87) 
W.B.Yeats, one of the most influential English poets of the $20^{\text {th }}$ century, depicted the typically Western image of the 'Tragic Hero' and spoke of the 'pathetic gaiety' that characterizes the wisdom of the west. Yeats tries to balance the "Asiatic vagueness in the blank eye-balls of Buddha" with the "Measurement" which began their "Might". This kind of "Laughing to the tomb" attitude of the western hero has its roots in the Greek and Roman civilizations and literature, and these cultural foundations have been revealed by Will Durant in an extremely absorbing manner.

Durant lays bare these foundations by quoting profusely from great Roman luminaries like Lucretius, Ovid and also Cicero. Lucretius, who was a poet and a philosopher, proclaimed that "Nothing Exists but Atoms and the Void". He also spoke of the soul (anima) as a "vital breath" which is spread as a very fine matter throughout the body and animates every part. It grows and ages with the body and its atoms are apparently dispersed when the body dies. Hence, life should be looked upon essentially as "given to us not in free hold but on loan, and for good so long as we can make good use of it". Here, comes in a statement of Lucretius, the central idea of the tragic hero: "When we have exhausted our powers, we should leave the table of life as graciously as a grateful guest rising from a feast." (Will Durant, 2001, p.122)

Another popular figure, Lucius Cornelius Sulla, famous as 'Sulla Felix', meaning 'Sulla the Happy', displayed the same attitude towards life. Durant narrated his story and presented his epitaph which again highlights this element: "No friend ever served me, and no enemy ever wronged me, whom I have not repaid in full". (Will Durant, 2001, p.131)

The ring of tradition becomes more prominent when we look at the frighteningly dispassionate final statement of Augustus, the greatest of Roman statesmen, who lived towards the closing decades of the Pre-Christian era: "Since well I've played my part, clap now your hands, and with applause dismiss me from the stage." (Will Durant, 2001, p.148)

This cold-eyed dismissal of the pleasures and pains of life in one go forged the fundamental precepts of the western mind for millennia which permeate the recurring themes of its literature. Durant has brought this synthesis out beautifully between the two covers.

\section{The Less KnOWn FACETS OF RenaisSAnCE Literature}

Every avid student of literature knows about Renaissance (1335-1596) as a cultural movement that was characterized by a passion in the imitation and recreation of the Roman, and a little later, Greek past. It was, as it is described, "pertaining to ethical conduct and the reach for objective truth unhampered by faith and mysticism". In addition to these core impulses that constituted the Renaissance lore, Durant brings out another angle, the underlying stimulus for all Renaissance thought. He, while elaborating on Boccaccio's Decameron which is considered the trigger of Renaissance literature, consolidated his argument thus:

"So, in its very infancy, the Renaissance was voting for delights and challenges of this earthly world instead of the hypothetical pleasures of a postmortem paradise. The Renaissance restored not only the literature of classical antiquity, but equally its pursuit of a hedonistic freedom. It was in part a pagan liberation of the senses after a thousand years of moral discipline resting on supernatural beliefs". (Will Durant 2001, p.186)

This hidden element explains all the passions of Renaissance, even the uncharted maritime exploits of the Europeans which ultimately resulted in the discovery of new lands and colonization.

Durant, in his presentation of the lives and works of men that have left profound impact on literature and life, has given the 'conflict, crisis and culmination' of their mission. He has provided an analysis as well as synthesis of the events in their life vis-à-vis the contributions they made, against the broad canvas of their times. This bestows on the reader of literature a balance in his/her judgment of things in the absence of which he may be led to hasty and incongruous notions. Durant proffers a perspective in explaining the life-graphs of the two prominent figures of Renaissance and Enlightenment periods, viz., William Shakespeare and Francis Bacon, as embodying all essential elements and the ethos of those turbulent times. He startles the readers by showcasing the element of pessimism in Shakespeare by quoting sumptuously from the playwright's most popular works:

"All the illuminees of the English-speaking worlds are familiar with the themes and delights of the thirty-seven plays that Shakespeare wrote, in part or in whole, but perhaps too little wonder has been expressed at the almost brutal cynicism that sometimes cries out in one play after 
another. Amid the happy splendour of their style there cries out an almost cynical note of anguish, even in the lighthearted comedies..." (Will Durant 2001, p.308)

Durant exposes Monsieur Melancholy Jacques' words that the only certainty in life is death; Hamlet's view that "world is an unweeded garden that grows to seed; things rank and gross in nature Possess it nearly"; the fact that Desdemona in 'Othello', who stands for goodness, honesty and fidelity, is murdered; the murderer's merciless judgment on life in 'Macbeth', that life is "a tale told by an idiot, full of sound and fury, signifying nothing", and Timon's hatred towards humanity in 'Timon of Athens' that in an ecstasy of hatred he bids nature cease breeding men, and hopes that vicious beasts may multiply to wipe out the human race. Durant explains that the "excesses of this misanthropy, such a 'reducto ad nauseum' suggests that the disease was purging itself, and that Shakespeare would smile again." (Will Durant 2001, p.308-09) Durant agrees that Shakespeare became more optimistic towards life and world in his final plays but it was "a hesitant recognition that, amid the evils of this world, there are blessings and delights, amid the villains many heroes and some saints - for every Iago a Desdemona, for every Goneril a Cordelia, for every Edmund and Edgar or a Kent; even in Hamlet a fresh wind blows from Horatio's faithfulness and Ophelia's wistful tenderness." (Will Durant 2001, p.309)

After this illuminating analysis of Shakespeare's inner impulses, Durant summarizes the playwright's shift to belief in life and triumph of the virtuous over the wily by attributing it to the final journey of Shakespeare to his hometown, thus synthesizing poet's life and his output. Here is the final say of Durant on the culmination of Shakespearean evolution: "After the tired actor and playwright leaves the consuming chaos and crowded loneliness of London for the green fields and family love of his Stratford home, he will recaptures the strong man's love of life." (Will Durant 2001, p.309-10)

Durant then proceeds to present the rise and fall of Francis Bacon. He brings to focus all the acts, decisions and tribulations of Bacon's extraordinary life in such a way that the reader could at once find the cool resignation and ingenuity which characterize his essays as mere reflections of his personality traits which were unfolded in his stormy political career. After his trial and release, "the chastened chancellor retired to Gorhambury and tried to live more simply. In cipher, on paper left by Bacon at his death, his first biographer, Rawley, found the famous statement, "I was the justest judge that was in England these fifty years. But it was the justest censure in Parliament that was these 200 years." Durant provides many intriguing historical facts which show the gigantic stature of Bacon who was the initiator of an era in world history.

"When Englishmen founded the Royal Society of London for Improving Natural Knowledge (1660), it was Francis Bacon who was honoured as its inspiration, and Salomon's House in The New Atlantis probably pointed its goal. Leibniz hailed Bacon as the regenerator of philosophy. And when the philosophes of the Enlightenment put together their world-shaking Encyclopedie (1751), they dedicated it to Francis Bacon." (Will Durant 2001, p.328)

Durant places Francis Bacon at the head of the Age of Reason. Durant draws a profound observation which illustrates a historic change on a world scale:

"He raised a banner for all the sciences, and drew to it the most eager minds of the succeeding centuries. Whether he willed it or not, the enterprise that he called for - the comprehensive organization of knowledge - contained in itself the seeds of the profoundest drama of modern times: Christianity, Catholic or Protestant, fighting for its life against the spread and power of science and philosophy. That drama had now spoken its prologue to the world." (Will Durant 2001, p.329)

\section{Conclusion}

In addition to imparting the enigmatic knowledge of times, Will Durant enriches the passionate readers of literature with the etymological and contextual origins of many words which are still in vogue. The famous king Solomon of the Old Testament owes his name to 'Shalom' meaning 'Peace'. This, indeed, may be the root of 'Salam', the most common greeting or gesture of respect and courtesy we come across. A reader of Will Durant will be immensely benefited by both the remote historical information that underlies the themes and springs of literature and the balanced standpoint which is most essential for a mature understanding of life and its vagaries. The culmination of Durant's interpretation could be seen in the following statement to which he arrived after taking the entire story of world civilization in his stride: "A little knowledge of history stresses the variability of 


\section{Prof.V.V.Hanumantha Rao}

moral codes, and concludes that they are negligible because they differ in time and place, and sometimes contradict each other. A larger knowledge stresses the universality of moral codes, and concludes to their necessity." (Will Durant, 2010.p.37). This snippet from Durant's colossal corpus of writings could be perceived as the summum bonum of all literary creation.

\section{REFERENCES}

[1] Durant, W. (2002). Heroes of history: A brief history of civilization from ancient times to the dawn of the modern age. Simon and Schuster.

[2] Durant, W.(2002). The Greatest Minds and Ideas of All Time. Simon and Schuster.

[3] Durant, W.(2010). The Lessons of History. Simon and Schuster.

[4] Poplawski, P. (2008). English literature in context. Cambridge University Press.

[5] Ullmann,H.F. (2010). The story of Literature: From Antiquity to the present.

\section{AUTHOR's BIOGRAPHY}

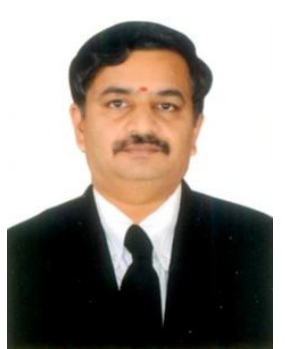

Dr.V.V.Hanumantha Rao, Professor of English, has been teaching at Sri Vasavi Engineering College for 15 years now. He has been editing 'SUPATHA', a bilingual, bimonthly magazine since 1998 . He has a penchant for poetry, literature and Indian history and has spoken from many platforms on Indian culture, heritage and various historical sites in the country. He authored a book on Telugu film lyrics, "Telugu Chitra Saraswathi" in 1995. He provided script assistance for the Nandi award (Special Jury) winning feature film, "Gautama Buddha", scripted by Dr.K.Sivananda Murty in 2007 and did 'research and compilation' for a documentary film "In Search of Buddha" (A documentary seeking the foot prints of the Buddha in ancient India), produced as a DVD in 2013. 